\title{
INVESTIGATING IMPACT OF SERVICE AND HYGIENE ON HOTEL REPUTATION DURING THE COVID -19 PANDEMIC: A PERSPECTIVE SIGNALING THEORY
}

\author{
Juliana $^{1)}$, Amelda Pramezwary ${ }^{2)}$, Madeline ${ }^{3)}$, Nadya Valerie $^{4)}$, Sylena Teresia Andrian ${ }^{5)}$, Venty \\ Ventyani')
}

$1,2,3,4,5)$ School of Hospitality \& Tourism, Pelita Harapan University, Indonesia

Accepted 1 October 2021/ Approved 26 November 2021

\begin{abstract}
Providing good service to consumers by a company can create customer satisfaction. Two aspects of service quality that play a significant role, in this case, our hotel services and hotel cleanliness. To get around this, entrepreneurs engaged in this field are increasingly competitive in improving service quality, which can meet consumers' needs and desires so that they can compete and develop in competitive conditions. In this study, researchers used the variable dimensions of service quality and hotel cleanliness as The variables that are expected to explain a hotel's good and bad reputation. This study aimed to analyze the effect of hotel services and hotel cleanliness on hotel reputation. This research method is descriptive quantitative with the type of research explanation. This study's population was hotel visitors in Tangerang, with a final sample of 157 respondents selected by the non-probability sampling technique. Methods of data analysis using PLS-SEM. The research shows that the higher the hotel services application will not affect the hotel's reputation during the Covid 19 pandemic. In comparison, the higher the application of hygiene involves the hotel's importance because, during the Covid 19 pandemic, the application of CHSE is the most important in maintaining the reputation of the hotel.
\end{abstract}

Keywords: Hotel Service, Hygiene, Hotel Reputation

\section{PENDAHULUAN}

Unexpected events, such as the COVID-19 pandemic, natural disasters, and terrorist threats, placed the hotel industry at risk (Chan and Lam, 2013; Chen, 2011; Hung et al., 2018; Paraskevas, 2013). Different forms of disasters have different industrial effects, and hoteliers must solve the crises' myriad challenges. Today's market growth is driven by society's diverse attitude. Everyone is getting more picky on the quality of services delivered by each industry. Tourism is one of the markets that has a major effect on both big and small businesses. The more visitors who visit a tourist destination or an area's creation, the more accommodation facilities are needed.

*Korespondensi Penulis:

E-mail: juliana.stpph@uph.edu
Hotels are one of the service industries in the tourism sector that offer elements of service, luxury, and other services for those with business and leisure interests. This establishment's primary feature is room rental or hotel facilities. Apart from that, hotels must have the highest level of service to their clients. Covid-19, a new form of infection that appeared at the end of 2019, has brought nearly all world economies to a halt. The virus was first discovered in Wuhan, China, in December 2019 and was declared a pandemic by the World Health Organization. Since the virus was declared a pandemic, governments have adopted World Health Organization-recommended interventions such as social scale limits, maintaining a safe distance, and wearing masks. Countries are implementing the change as part of a preventative plan to slow 


\section{Versi Online:}

https://journal. ubm.ac.id/index.php/hospitality-pariwisata Doi: http://dx.doi.org/10.30813/jhp.v7i2.2734 Hasil Penelitian

the transmission of the virus and prevent a rise in deaths.

Actions taken at the international level to combat the COVID-19 pandemic have a significant impact on the hotel industry in terms of revenue, consumers, and workers. In several countries, the closing of airlines, beaches, hotels, bars, bars, and clubs has caused headlines (Baum et al., 2020). The tourism industry is one of the most impacted industries by the COVID-19 pandemic, with analysts and economists agreeing that the hotel and leisure market is actually facing the most direct effects (Gursoy and Chi, 2020). Several WHO-recommended steps to deter the virus's spread include limiting travel. Cross-border transport and migration are particularly important to the hotel industry (Baum and Hai, 2020; Jiang and Wen, 2020). Many studies have attempted to assess the influence of the COVID-19 pandemic on global economic development (Ashraf, 2020; Baker et al., 2020; Bonaccorsi et al., 2020; Zhang et al., 2020). The bulk of these articles concentrate on its impact on capital markets, corporate and general exchanges, and cross-national trade ties. Others also shared useful knowledge about how the COVID-19 pandemic has impacted the hotel industry (Gursoy and Chi, 2020; Jiang and Wen, 2020). According to Nunkoo et al. (2020), the business can boost efficiency to compete in a dynamic environment, maintain current clients, and gain new customers, so customer loyalty is the primary strategy. Service level is dictated by prior preferences and current consumer impressions, according to (Chen and Chen, 2014). The effectiveness of a hospitality industry is determined by service efficiency, which has five dimensions: tangibles, accessibility, responsiveness performance, and empathy. These five dimensions would have an effect on consumer loyalty with a company's services. As a result, governments will assess the degree of customer loyalty by improving service quality efficacy (Afthanorhan et al., 2019). A business that provides excellent service to customers can generate customer satisfaction. Our hotel facilities and hotel cleanliness are two facets of service efficiency that play a major role in this situation. To get around this, entrepreneurs in this sector are becoming more innovative in terms of optimizing service quality to satisfy the demands and expectations of customers, allowing them to thrive and thrive in challenging environments. Hygiene may also be characterized as the method of planning for and ensuring desirable health conditions (Yu et al., 2021). Hotel clients, in fact, have only fleeting encounters with hotel goods and services and grow an emotional response to them. As a result, hotel product and service cleanliness is a crucial factor in assessing hotel-centered customer conduct such as customer loyalty, perceived service efficiency, and return visit intentions. (Nunkoo et al., 2020) performed a related report, which found that room safety and efficiency are two important determinants of satisfaction with three-star hotel companies, despite their poor results. Pizam \& Tasci (2019) demonstrate how a comprehensive and rewarding experience will entice customers to return. Since power resides in the expectations and opinions of consumers as they hear the organization's name, credibility is considered an important element in the overall appraisal of any organization in the hospitality industry (Bitner, 1990, 1991; Gronroos, 1984; Sarstedt et al., 2012). (Bravo et al., 2009; Nguyen, 2006). Signaling theory, according to the authors, will help service providers resolve customer concerns before and during a pandemic. This is because signs, which can be seen as observable measures of hidden consistency that consumers can act on (Bergh et al., 2014), have the ability to minimize market anxiety and influence buying decisions (Bente et al., 2012). Consumers looking for signals of a visual sign that provides details about unobservable attributes and potential outcomes during the Covid 19 pandemic face fragmented and asymmetrical scattered information about the protection of service providers, so they search for signals of a visual sign that provides information about unobservable attributes and possible outcomes (Spence, 1974). Signaling theory sets the groundwork for an interpretation, as signals can establish a separating equilibrium, helping consumers to navigate 
information challenges and accomplish their objectives (Bergh et al., 2014). As a result, successful signs allow customers to distinguish or separate between highquality service providers. The two styles of consistency are high and poor. When the predicted signal output is realized in the next consumer encounter, this is known as signal validation (Bergh et al., 2014). In the analysis, the problem is specified. Will the hotel's credibility suffer as a result of the service? Would the hotel's reputation suffer as a result of poor hygiene? The aim of the analysis was to look at the effects of hotel facilities and cleanliness on hotel credibility.

The partnership between a service hotel and a hotel with a strong reputation

According to Mutle's (2017) study, service quality has an effect on a hotel's image because poor service often leads to unpleasant talks and bad news for hotels. Service efficiency has also been shown to mediate the association between hotel appearance and credibility in other research (Lai \& Ivan, 2019). Hotel managers must boost service quality in order to create a favorable image for their businesses (Chen \& Chen, 2014; Upanun \& Sornsaruht, 2020), as service quality has an impact on hotel reputation (Chen \& Chen, 2014; Upanun \& Sornsaruht, 2020). Service levels, according to (Jalbani \& Soomro, 2017), have an effect on the hotel's importance. The hypothesis can be stated as follows based on the above description:

H1: the higher the standard of hotel service implementation, the higher the hotel's prestige.

\section{The correlation between hotel cleanliness and reputation}

Consumer expectations for the value of a hotel are affected by a variety of factors. The hotel's sanitation is one of the deciding factors (Fung \& Hamzah, 2020). Hygiene has also been shown to be a significant factor in fostering customer happiness and engagement in previous studies (Barber, 2011). This study showed that consumers' cleanliness can change a company's image and is also a key factor in forecasting consumer decision-making and buying behaviour, based on existing studies. As a result, based on current studies, this thesis suggests the following theories.

$\mathrm{H} 2$ : the higher the standard of hotel hygiene implementation, the higher the hotel's prestige.

\section{RESEARCH METHODS}

This research method is quantitative with the type of explanatory research (explanatory research). This study's population was hotel visitors in Tangerang, with a final sample of 157 respondents using a non-probability sampling technique. The questionnaires were distributed online via a google form. The analysis technique uses PLS-SEM. This research is a descriptive quantitative study examining the dependent variable's independent relationship (Sekaran \& Bougie, 2018). Roscoe (1975); Sekaran \& Bougie (2018) suggest that for multivariate research, the sample size should be several times (preferably ten times or more) larger than the number of variables studied. . The questionnaire was distributed online using a 1-7 point Likert scale. The statistical analysis is based on SmartPLS. This study's latent variable consists of three variables: service hotel and hygiene hotel variables are independent variables; hotel reputation is the dependent variable.

\section{RESULTS AND DISCUSSION}

The data that has been obtained in the research are then analyzed using the instrument test. In this study, the instrument test was carried out to see the validity and reliability of the data obtained in the study with existing data. From the validity and reliability tests that have been obtained, it is then used as a reference material for use in further tests. The variables to be tested in this study are service hotel, hygiene hotel and hotel reputation.

The research was conducted by giving questionnaires to 157 respondents and obtained respondent data in the form of age, profession and tabulation of answers about the study.

The characteristics of respondents in the study are presented in the following table:

\section{Table 1. Respondent Profile}

\begin{tabular}{lcc}
\hline $\begin{array}{l}\text { Respondent } \\
\text { Data }\end{array}$ & Description & $\begin{array}{c}\text { Total } \\
\text { Respondent }\end{array}$ \\
\hline
\end{tabular}




\begin{tabular}{|c|c|c|}
\hline \multirow[t]{5}{*}{ Age } & $<20$ years & 113 \\
\hline & 21-30 years & 21 \\
\hline & $31-40$ years & 10 \\
\hline & $>40$ years & 13 \\
\hline & Total & 157 \\
\hline \multirow[t]{5}{*}{ Profession } & $\begin{array}{c}\text { Un } \\
\text { employment }\end{array}$ & 7 \\
\hline & Student & 116 \\
\hline & Employee & 18 \\
\hline & Entrepreneur & 16 \\
\hline & Total & 157 \\
\hline
\end{tabular}

Source: obtained from primary data (2021)

The characteristics of the respondents in the study were as follows:

1. Based on table 1 , it is known that the characteristics of respondents are dominated by respondents who are less than 20 years old with a total of 113 respondents, while the rest are 21-30 years old with a total of 21 respondents. A total of 14 respondents aged between 31-40 years, and as many as 13 respondents were over 40 years old.

2. Based on table 1, the respondents' characteristics are dominated by respondents who are students with a total of 116 respondents. In comparison, the rest have the profession as employees with the number of respondents as many as 18 respondents A total of 16 respondents have a career as entrepreneurs and as many as 7 respondents unemployment .

\section{Figure 1. Design of The Research Model}

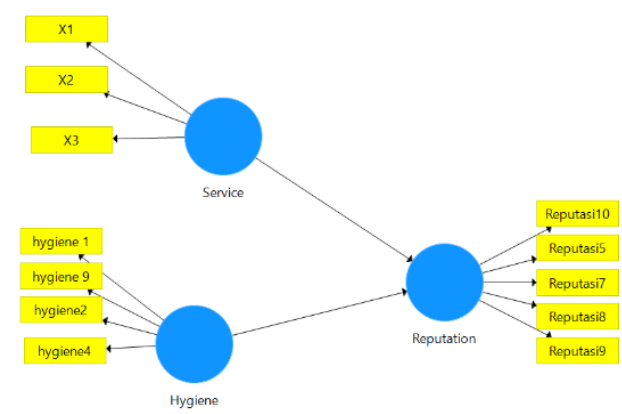

Source: obtained from primary data (2021)

\section{Evaluation of Measurement Model (outer model)}

The measurement model's evaluation consists of three stages: the convergent validity test, the discriminant validity test, and the composite reliability test.

Validity testing for reflective indicators can be done by using a correlation between the indicator score and the construct score. Measurements with reflective indicators show a change in an indicator in a construct when other indicators in the exact construct change. Following are the results of calculations using the Smart PLS 3.0 computer program

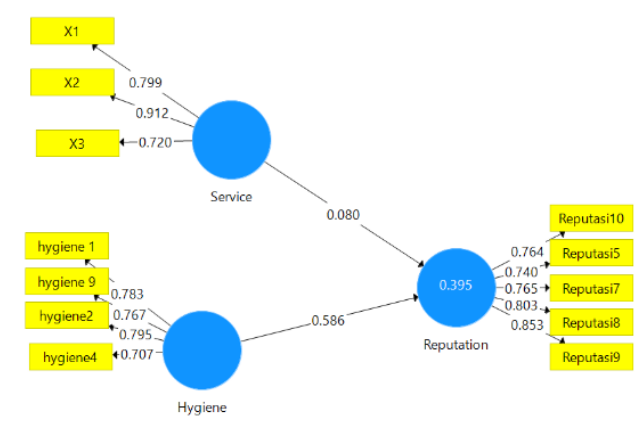

Source: obtained from primary data (2021)

According to (Ghozali \& Latan 2015), a correlation can be said to meet convergent validity if it has a loading value greater than 0.5 . The output shows that the loading factor provides a value above the recommended Value of 0.5 . so that the indicators used in this study have met the convergent validity.

\section{Discriminant Validity Test}

The significance of the inequality must be checked in the reflective predictor by comparing the cross-loading table values. If an indicator's loading factor value for the intended construct is higher than the loading factor value for the other constructs, it is declared true. Cross-loading of predictor, Fornell \& Larcker criteria, and Heterotraitmonotrait (HTMT) ratio of association can all be used to determine discriminant validity. When looking at cross-loading, the factor loading indicators on the assigned construct must be higher than all other loading indicators, with the restriction that the factor loading cut-off value is greater than 0.70. (Hair et al., 2019, 2014). If the HTMT is less than 0.90 for conceptually equivalent constructs, it indicates a problem with discriminant validity. If the HTMT is greater than 0.90 , it indicates a problem 
with discriminant validity (Henseler et al., 2015).

Table 2. Cross Loading Output

\begin{tabular}{|c|c|c|c|}
\hline $\begin{array}{c}\text { Con } \\
\text { struc } \\
\mathrm{t}\end{array}$ & $\begin{array}{l}\text { Hy } \\
\text { gie } \\
\text { ne }\end{array}$ & $\begin{array}{c}\text { Rep } \\
\text { utati } \\
\text { on }\end{array}$ & $\begin{array}{l}\text { Se } \\
\text { rv } \\
\text { ic } \\
\text { e }\end{array}$ \\
\hline $\begin{array}{c}\text { Rep } \\
\text { utasi } \\
10\end{array}$ & & $\begin{array}{c}0.76 \\
4\end{array}$ & \\
\hline $\begin{array}{c}\text { Rep } \\
\text { utasi } \\
5\end{array}$ & & $\begin{array}{c}0.74 \\
0\end{array}$ & \\
\hline $\begin{array}{c}\text { Rep } \\
\text { utasi } \\
7\end{array}$ & & $\begin{array}{c}0.76 \\
5\end{array}$ & \\
\hline $\begin{array}{c}\text { Rep } \\
\text { utasi } \\
8\end{array}$ & & $\begin{array}{c}0.80 \\
3\end{array}$ & \\
\hline $\begin{array}{c}\text { Rep } \\
\text { utasi } \\
9\end{array}$ & & $\begin{array}{c}0.85 \\
3\end{array}$ & \\
\hline $\begin{array}{l}\text { Serv } \\
\text { ice1 }\end{array}$ & & & $\begin{array}{c}0 . \\
79 \\
9 \\
\end{array}$ \\
\hline $\begin{array}{l}\text { Serv } \\
\text { ice2 }\end{array}$ & & & $\begin{array}{c}0 . \\
91 \\
2 \\
\end{array}$ \\
\hline $\begin{array}{l}\text { Serv } \\
\text { ice3 }\end{array}$ & & & $\begin{array}{c}0 . \\
72 \\
0 \\
\end{array}$ \\
\hline $\begin{array}{c}\text { Hygi } \\
\text { ene } \\
1 \\
\end{array}$ & $\begin{array}{l}0.7 \\
83\end{array}$ & & \\
\hline $\begin{array}{c}\text { Hygi } \\
\text { ene } \\
9\end{array}$ & $\begin{array}{l}0.7 \\
67\end{array}$ & & \\
\hline $\begin{array}{l}\text { Hygi } \\
\text { ene } \\
2\end{array}$ & $\begin{array}{l}0.7 \\
95\end{array}$ & & \\
\hline $\begin{array}{l}\text { Hygi } \\
\text { ene } \\
4\end{array}$ & $\begin{array}{l}0.7 \\
07\end{array}$ & & \\
\hline
\end{tabular}

Source: obtained from primary data (2021)

Table 3. HTMT Ratio

\begin{tabular}{cccc}
\hline $\begin{array}{c}\text { Con } \\
\text { struc } \\
\mathrm{t}\end{array}$ & $\begin{array}{c}\text { Hy } \\
\text { gie } \\
\text { ne }\end{array}$ & $\begin{array}{c}\text { Rep } \\
\text { utati } \\
\text { on }\end{array}$ & $\begin{array}{c}\text { Se } \\
\text { rvi } \\
\text { ce }\end{array}$ \\
\hline $\begin{array}{c}\text { Hyg } \\
\text { iene }\end{array}$ & & & \\
\hline $\begin{array}{c}\text { Rep } \\
\text { utati }\end{array}$ & 0.7 & & \\
on & 72 & & \\
\hline Serv & 0.6 & 0.45 & \\
ice & 28 & 9 &
\end{tabular}

Source: obtained from primary data (2021)
Table 3 shows that the study indicators are appropriate and appropriate to test the construct because they have a discriminant value below 0.9 .

Table 4. Fornell \& Larcker Criterion

\begin{tabular}{|l|l|l|l|}
\hline Construct & Hygiene & Reputation & Service \\
\hline Hygiene & 0.764 & & \\
\hline Reputation & 0.625 & 0.786 & \\
\hline Service & 0.483 & 0.363 & 0.814 \\
\hline
\end{tabular}

Source: obtained from primary data (2021)

The evaluation of discriminant validity uses the Fornell-Lacker criterion. According to Hair et al. (2014), the Fornell-Lacker criterion compares the Value of AVE's square root with the correlation between variables. Discriminant validity is fulfilled if the AVE's square root value for each variable is greater than the correlation value between the model variables. In table 4 , it can be seen that the Value of the square root AVE of each variable is greater than the correlation value between variables. Therefore, it can be concluded that this study has met the requirements of the discriminant validity test.

\section{Reliability Test and Convergent Validity}

According to Hair et al. (2019), a latent variable can have good reliability if the composite reliability value is greater than 0.7. The Cronbach's alpha value is more significant than 0.7 . The AVE value $\geq 0.5$, according to Hair et al. (2019), it is stated that each construct meets the convergent validity requirements

Table 5. Reliability Test Results and Average Variance Extracted (AVE)

\begin{tabular}{lllll}
\hline Construct & $\begin{array}{l}\text { Cronbach's } \\
\text { Alpha }\end{array}$ & $\begin{array}{l}\text { Composite } \\
\text { Reliability }\end{array}$ & AVE & Result \\
\hline Hygiene & 0.762 & 0.848 & 0.583 & $\begin{array}{l}\text { Valid } \\
\text { and } \\
\text { Reliabl } \\
\text { e }\end{array}$ \\
\hline Reputation & 0.844 & 0.890 & 0.618 & $\begin{array}{l}\text { Valid } \\
\text { and } \\
\text { Reliabl } \\
\end{array}$ \\
& & & & \\
& & & & \\
\hline
\end{tabular}


Versi Online:

https://journal, ubm.ac.id/index.php/hospitality-pariwisata

Doï: http://dx.doi.org/10.30813/jhp.v7i2.2734

Hasil Penelitian
Jurnal Hospitality dan Pariwisata

Vol.7 (No. 2): 72 - 81. Th. 2021

p-ISSN: 2442-5222

e-ISSN: 2655-8165

\begin{tabular}{lllll}
\hline Service & 0.740 & 0.854 & 0.663 & Valid the $\mathrm{R}^{2}$ Value $>0.75$ is said to be substantial
\end{tabular} and if the $\mathrm{R}^{2}$ Value is $0.5-0.75$, it is moderate; if Reliahthe $\mathrm{R}^{2}$ Value is $<, 0.5$ it is said to be weak. e The $R^{2}$ result for the reputation variable is

Source: obtained from primary data (2021)

Table 5 shows that all latent variables measured in this study have Cronbach's alpha and composite reliability values greater than 0.7 , so it can be said that all latent variables are reliable and all constructs meet the convergent validity requirements.

\section{Evaluation of the Structural Model (Inner Model)}

Evaluation of the structural model in S.E.M. with P.L.S. is carried out by performing the R-Squared $\left(\mathrm{R}^{2}\right)$ test and significance test through the path coefficient estimation

\section{Multicollinearity Testing}

According to (Hair et al., 2019), criterion Multikolinearity > 10: Critical, 5-10: probable, 3-5: suggested, < 3: ideal

Table 6. V.I.F.- Variance Inflation Factor

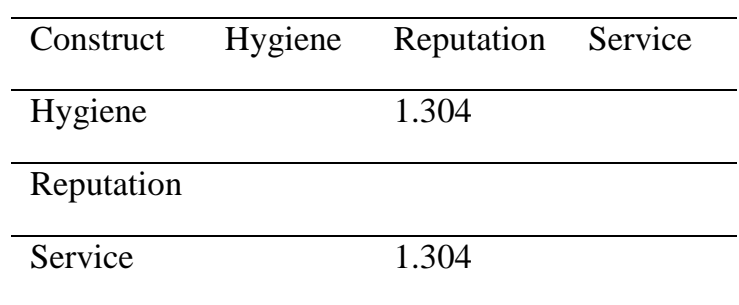

Source: obtained from primary data (2021)

Table 6 shows that there is no multicollinearity problem, and the independent variables are not correlated.

$R$ Squared $\left(\mathbf{R}^{2}\right)$ Testing The

Coefficient of Determination

Output for $\mathrm{R}^{2}$ Value using smart PLS

3.0 computer program is obtained

Table 7. $\mathbf{R}^{2}$ Calculation Output

\begin{tabular}{ccc}
\hline Construct & R Square & $\begin{array}{c}\text { R Square } \\
\text { Adjusted }\end{array}$ \\
\hline Reputation & 0.395 & 0.387 \\
\hline Source: obtained from primary data $(2021)$
\end{tabular}

$\mathrm{R}$-Squared $\left(\mathrm{R}^{2}\right)$ value is used to measure how much influence a specific independent latent variable has on the latent dependent variable. According to (Hair et al., 2014) if 0.395, indicates that the model is categorized as weak. Table 7 shows that the $\mathrm{R}^{2}$ Value of this study is weak

\section{Significance Test}

The S.E.M. model's significance test with P.L.S. aims to analyze exogent variables' effect on endogenous variables. Hypothesis testing with the PLS-SEM method is carried out by carrying out the bootstrapping process with the help of the smart PLS 3.0 computer program so that the relationship between the influence of exogenous variables on endogenous variables is obtained as follows

\section{Table 8.Q Squared Predict $\left(Q^{2}\right)$}

\begin{tabular}{lc}
\hline Construct & $\mathrm{Q}^{2}$ Predict \\
\hline Reputation & 0.361 \\
\hline Source: obtained from primary data (2021)
\end{tabular}

According to Hair et al. (2019) $\mathrm{Q}^{2}$ Predict > $0-0,25$ : small predictive, $0,25-0,50$ : medium predictive, $0,50:$ large predictive. The research model has a medium predictive value because it has a $\mathrm{Q}^{2}$ predict value between 0.25-0.50. According to Hair et al. (2019), significance is $\mathrm{T}$ statistic $>\mathrm{T}$ Table's 1.645

Table 9. Hypothesis Test

\begin{tabular}{lllll}
\hline Hyphotesis & $\begin{array}{l}\text { Standa } \\
\text { rdized } \\
\text { Coeffi } \\
\text { cient }\end{array}$ & $\begin{array}{l}\mathrm{T} \\
\text { Stati } \\
\text { stics }\end{array}$ & $\begin{array}{l}\mathrm{P} \\
\text { val } \\
\text { ues }\end{array}$ & $\begin{array}{l}\text { Resul } \\
\mathrm{t}\end{array}$ \\
\hline $\begin{array}{l}\text { Hygiene } \rightarrow \\
\text { Reputation }\end{array}$ & 0.064 & 9.19 & 0.0 & $\begin{array}{l}\text { Supp } \\
\text { orted }\end{array}$ \\
\hline $\begin{array}{l}\text { Service } \rightarrow \\
\text { Reputation }\end{array}$ & 0.077 & 1.03 & 0.3 & $\begin{array}{l}\text { Not } \\
\text { Supp } \\
\text { orted }\end{array}$ \\
& & 6 & 00 & \\
\end{tabular}

Source: obtained from primary data (2021)

The $\mathrm{T}$ statistic $>\mathrm{T}$ Table's significance is 1,645. Research shows that Hypothesis 2 is not supported; the higher the hotel's application at the hotel does not affect the 
hotel's reputation during the Covid 19 pandemic. In comparison, the higher the application of hotel hygiene will affect the hotel's reputation during the Covid 19 pandemic where $\mathrm{T}$ statistics $<\mathrm{T}$ Table's and hypothesis 1 supported.

The $\mathrm{R}^{2}$ value in this study is fragile, so that it cannot predict and explain the dependent variable in the context of staying at a hotel in Tangerang. The study results prove that the service variable has no effect on the reputation of the hotel, and the hypothesis is not supported; this is contrary to the results of research from (Mmutle, 2017; Upanun \& Sornsaruht, 2020). The results of the research state that the hygiene variable affects the reputation of the hotel. The hypothesis is supported by this, in line with research conducted by (Jiang \& Wen, 2020), which states that hygiene can go beyond sanitation to cover broader health aspects. Consumers tend to be more concerned about health protocols when planning trips after the COVID-19 pandemic. Guests prioritize their health and hygiene, such as implementing health protocols, maintaining a healthy diet, and regular rest.

\section{CONCLUSION}

Based on the research objectives, data analysis using PLS-SEM shows that the higher the application of hotel services will not affect the hotel's reputation during the Covid 19 pandemic. In comparison, the higher the application of hygiene affects the hotel's reputation because during the Covid 19 pandemic, the implementation of CHSE and the essential health protocol in maintaining the reputation of the hotel. Signaling theory provides valuable insights to assist service providers in hotel recovery efforts after a pandemic. Although this study has provided empirical data that can explain practical and theoretical implications, some limitations need to be investigated. The sample for research is limited only to respondents who have stayed at hotels in Tangerang. Antecedents of hotel reputation can be carried out further research by adding other variables, which are it is essential to increase the explanatory power of the research model. In taking the sample only using google form so that the research is not less generalized

\section{REFERENCES}

Afthanorhan, A., Awang, Z., Rashid, N., Foziah, H., \& Ghazali, P. L. (2019). Assessing the effects of service quality on customer satisfaction. Management Science Letters, 9(1), 13-24.

https://doi.org/10.5267/j.msl.2018.11. 004

Ashraf, B. N. (2020). Economic impact of government interventions during the COVID-19 pandemic: international evidence from financial markets",Journal of Behavioral and Experimental Finance, Vol. 27.

Baker, S.R., Farrokhnia, R.A., Meyer, S., Pagel, M. and Yannelis, C. (2020). How does household spending respond to an epidemic? Consumption during the 2020 Covid-19 pandemic (No. w26949)", National Bureau of Economic Research.

Barber, N. (2011). Restaurant consumers repeat patronage: A service quality concern. International Journal of Hospitality Management, 30(2), 329336.

Baum, T., Mooney, S., Robinson, R. and Solnet, D. (2020). COVID-19's impact on the hospitality workforce - new crisis or amplification of the norm?", International Journal of Contemporary Hospitality Management, Vol. 32 No. 9, pp. 28132829.

Baum, T. and Hai, N. (2020). Hospitality, tourism, human rights and the impact of COVID-19", International Journal of Contemporary Hospitality Management, Vol. 32 No. 7, pp. 23972407.

Bente, G., Baptist, O. and Leuschner, H. (2012). To buy or not to buy: influence of seller photos and reputation on buyer trust and purchase behaviour", International Journal of Human- 
Computer Studies, Vol. 70 No. 1, pp. $1-13$, doi: 10.1016/j.ijhcs.2011.08.005.

Bergh, D.D., Connelly, B.L., Ketchen, D.J., $\mathrm{Jr}$ and Shannon, L. M. (2014). Signalling theory and equilibrium in strategic management research: an assessment and a research agenda", Journal of Management Studies, Vol. 51 No. 8, pp. 1334-1360, doi: 10.1111/joms.12097.

Bitner, M. J. (1990). Evaluating service encounters: the effects of physical surroundings and employee responses", Journal of Marketing, 54(2), 69-82.

Bitner, M. J. (1991). The evolution of the services marketing mix and its relationship to service quality", in Brown, S., Gummesson, E., Edvardsson, B. and Gustavsson, B., Service Quality: A Multidisciplinary and Multinational Perspective, Lexington Books, New York, NY.

Bonaccorsi, G., Pierri, F., Cinelli, M., Flori, A., Galeazzi, A., Porcelli, F., Schmidt, A.L., Valensise, C. M., \& Scala, A., Quattrociocchi, W. and Pammolli, F. (2020). Economic and social consequences of human mobility restrictions under COVID-19", Proceedings of the National Academy of Sciences, Vol. 117 No. 27, pp. 15530-15535.

Bravo, R. Montaner, T. \& Pina, J. M. (2009). The role of bank image for customers versus Brown, S. P., (1995), "The moderating effects of insupplier/out-supplier status an organizational buyer attitudes", JAMS, 23(3), 170-181.

Chan, E.S. and Lam, D. (2013). Hotel safety and security systems: bridging the gap between managers and guests", International Journal of Hospitality Management, Vol. 32, pp. 202-216.

Chen, M. H. (2011). The response of hotel performance to international tourism development and crisis events",
International Journal of Hospitality Management, Vol. 30 No. 1, pp. 200212.

Chen, W. J., \& Chen, M. L. (2014). Factors Affecting the Hotel's Service Quality: Relationship Marketing and Corporate Image. Journal of Hospitality Marketing and Management, 23(1), 77-96.

https://doi.org/10.1080/19368623.201 3.766581

Fung, L. K., \& Hamzah, E. (2020). Factors Influencing the Preferences between Airbnb and Hotel. International Journal of Business and Technology Management, 2(3), 79-89.

Ghozali \& Latan. (2015). Partial Least Square S.E.M. (P.L.S. - S.E.M.). Partial Least Square. https://doi.org/10.1590/s180998232013000400007

Gronroos C. (1984). A service quality model and its marketing implications", European Journal of Marketing, 18, 36-44. 22.

Gursoy, D. and Chi, C. (2020). Effects of COVID-19 pandemic on hospitality industry: review of the current situations and a research agenda", Journal of Hospitality Marketing and Management, Vol. 29 No. 5, pp. 527529.

Hair, Black, W. C., Babin, B. J., \& Anderson, R. E. (2019). Multivariate data analysis.

Hair J, Hult GTM, Ringle C, S. M. (2014). A Primer on Partial Least Squares Structural Equation Modeling (PLSSEM) (Los Angeles: SAGE Publications, Incorporated).

Hair, J. F., Sarstedt, M., Hopkins, L., \& Kuppelwieser, V. G. (2014). Partial least squares structural equation modeling (PLS-SEM): An emerging tool in business research. In European Business Review. https://doi.org/10.1108/EBR-102013-0128 
Versi Online:

https://journal, ubm.ac.id/index.php/hospitality-pariwisata Doï: http://dx.doi.org/10.30813/jhp.v7i2.2734

Hasil Penelitian

Henseler, J., Ringle, C. M., \& Sarstedt, M. (2015). A new criterion for assessing discriminant validity in variancebased structural equation modeling. Journal of the Academy of Marketing Science, 43(1), 115-135.

Henseler, J., Ringle, C.M. and Sarstedt, M. (2015). A new criterion for assessing discriminant validity in variancebased structural equation modeling", Journal of the Academy of Marketing Science, Vol. 43 No. 1, pp. 115-135.

Hung, K.K., Mark, C.K., Yeung, M.P., Chan, E.Y. and Graham, C. A. (2018). The role of the hotel industry in the response to emerging epidemics: a case study of SARS in 2003 and H1N1 swine flu in 2009 in Hong Kong", Globalization and Health, Vol. 14 No. 1, p. 117.

Jalbani, S., \& Soomro, N. (2017). Determinants of Hotel's Service Standard: Reputation and Relationship Orientation. Journal of Tourism \& Hospitality, 06(01), 1-7. https://doi.org/10.4172/21670269.1000262

Jiang, Y. and Wen, J. (2020). Effects of COVID-19 on hotel marketing and management: a perspective article", International Journal of Contemporary Hospitality Management, Vol. 32 No. 8.

Jiang, Y., \& Wen, J. (2020). Effects of COVID-19 on hotel marketing and management: a perspective article. International Journal of Contemporary Hospitality Management, 32(8), 2563-2573. https://doi.org/10.1108/IJCHM-032020-0237

Joseph F. Hair, Jeffrey J. Risher, M. S. and C. M. R. (2019). When to use and how to report the results of PLS-SEM", European Business Review, Vol. 31 No. 1, pp. 2-24.

Lai, W., \& Ivan, K. (2019). Hotel image and reputation on building customer loyalty: An empirical study in Macau.
Journal of Hospitality and Tourism Management, 38, 111-121.

Mmutle, T. (2017). Customers' perception of service quality and its impact on reputation in the hospitality industry.

Nguyen, N. (2006). The collective impact of service workers and service scape on the corporate image formation", International Journal of Hospitality Management, 25(2), 227-44.

Nunkoo, R., Teeroovengadum, V., Ringle, C. M., \& Sunnassee, V. (2020). Service quality and customer satisfaction: The moderating effects of hotel star rating. International Journal of Hospitality Management, 91(November), 102414. https://doi.org/10.1016/j.ijhm.2019.1 02414

Paraskevas, A. (2013). Aligning strategy to threat: a baseline anti-terrorism strategy for hotels", International Journal of Contemporary Hospitality Management, Vol. 25 No. 1.

Pizam, A., \& Tasci, A. D. A. (2019). Experienscape: expanding the concept of servicescape with a multistakeholder and multi-disciplinary approach (invited paper for 'luminaries' special issue of International Journal of Hospitality Management). International Journal of Hospitality Management, 76(xxxx), 25-37.

https://doi.org/10.1016/j.ijhm.2018.0 6.010

Roscoe, J. T. (1975). Fundamental Research Statistics for the behavioral Sciences, 2nd edition, New York: Holt, Rinehart and Winston.

Sarstedt, M., Wilczynski, P. \& Melewar, T. C. (2012). Measuring reputation in global markets - A comparison of reputation measures' convergent and criterion validities", Journal of World Business, under press, 1-11.

Sekaran, Uma \& Bougie, R. (2018). Research Method for Business - A Skill Building-Approach, 7th Edition, 


\section{Versi Online:}

https://journal,ubm.ac.id/index.php/hospitality-pariwisata Doi: http: / / dx.doi.org/10.30813/jhp.v7i2.2734

Hasil Penelitian
Jurnal Hospitality dan Pariwisata Vol.7 (No. 2): 72 - 81. Th. 2021 p-ISSN: 2442-5222 e-ISSN: 2655-8165

John Wiley \& Sons, Ltd.

Spence, M. (1974). Competitive and optimal responses to signals: an analysis of efficiency and distribution", Journal of Economic Theory, Vol. 7 No. 3, pp. 296-332, doi: 10.1016/0022-0531(74) 90098-2.

Upanun, Kawee S. \& Sornsaruht, P. (2020). Factors affecting a Thai five-star hotel reputation: A SEM analysis.

Yu, J., Seo, J., \& Hyun, S. S. (2021). Perceived hygiene attributes in the hotel industry: customer retention amid the COVID-19 crisis. International Journal of Hospitality Management, 93(June 2020), 102768. https://doi.org/10.1016/j.ijhm.2020.1 02768

Zhang, J., Xie, C., Wang, J., Morrison, A.M. and Coca-Stefaniak, J. A. (2020). Responding to a major global crisis: the effects of hotel safety leadership on employee safety behavior during COVID-19", International Journal of Contemporary Hospitality Management, Vol. 32 No. 11, available at: https://doi.org/10.1108/IJCHM-042020-033. 